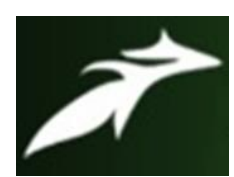

Saurabh Mishra et al, International Journal of Advances in Agricultural Science and Technology,

Vol.8 Issue.7, July-2021, pg. 69-75

ISSN: 2348-1358

Impact Factor: 6.057

NAAS Rating: 3.77

\title{
Knowledge of Farmers Towards Improved Wheat Production Practices in Prayagraj District of Uttar Pradesh
}

\author{
Saurabh Mishra*; Dr. Dipak Kumar Bose**; Prof. (Dr.) Ms. Jahanara*** \\ *Research Scholar, Department of Agricultural Extension \& Communication, SHUATS, Prayagraj \\ **Associate Professor, Department of Agricultural Extension \& Communication, SHUATS, Prayagraj \\ ***Head, Department of Agricultural Extension \& Communication, SHUATS, Prayagraj
}

DOI: 10.47856/ijaast.2021.v08i7.008

\begin{abstract}
The present investigation was conducted in Uruwa block of Prayagraj district, Uttar Pradesh. One hundred twenty respondents were selected randomly from 15 villages which were selected purposively. The primary data were gathered by the researcher itself through pre-structured interview schedule. Appropriate statistical tools were used to interpret the collected data to draw logical conclusion. The finding inferred that majority of farmers were having medium level of knowledge towards improved wheat production practices. Age, Education, land holding, Mass media exposure, Extension contacts, Economic motivation were observed positive and significant correlation with their knowledge level.
\end{abstract}

Keywords:- Knowledge, Production Practices, Wheat

\section{INTRODUCTION}

India is one of the important wheat producing and consuming countries in the world. The important wheat growing states are Punjab, Haryana, Uttar Pradesh, Bihar, Madhya Pradesh, Rajasthan and Gujarat in India. Wheat is the most extensively grown cereal crop in the world, covering about 237 million hectares annually, and accounting for a total of 420 million tones.

Wheat (Triticum aestivum) the world's largest cereal crop belongs to Graminae (Poaceae) family of the genus Triticum. It has been described as the "King of cereals" because of the acreage it occupies, high productivity and the prominent position in the international food grain trade. Wheat is consumed in a variety of ways such as bread, chapatti, porridge, flour, suji etc. For Wheat production target has been fixed in India for 2020 is 105.19 million tonnes against 100 million tonnes last year. Uttar Pradesh is the largest state with maximum contribution towards national production, but with productivity on a lower side of 2.7 tonnes/ha. (Anvesha $\boldsymbol{e t}$ al., 2020)

The present study was conducted to access the socio economic status of the respondents and to find out the knowledge of farmers towards improved wheat production practices. 


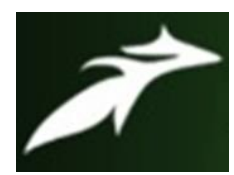

Saurabh Mishra et al, International Journal of Advances in Agricultural Science and Technology,

Vol.8 Issue.7, July-2021, pg. 69-75

ISSN: 2348-1358

Impact Factor: 6.057

NAAS Rating: 3.77

\section{MATERIALS AND METHODS:}

The present study was purposively undertaken in Uruwa block of Prayagraj district in Uttar Pradesh. Fifteen villages were purposively selected on the basis of majority of farmers practicing wheat cultivation. From each selected village, 8 farmers were selected randomly making a sample of 120 respondents. Pretested interview schedule was used for collection of data. The collected data were classified, tabulated and analyzed in the light of the objectives. Descriptive research design was followed and the variables were measured by using suitable scale and procedure adopted by various researchers in past with few modification. Appropriate statistical tools were used to draw the inferences.

\section{RESULTS AND DISCUSSION}

Socio-economical characteristics of the respondents:

The socio-economic characteristics of the respondents were studied and the data are given below.

Table 1:- Socio-economic characteristics wise distribution of the respondents $(\mathrm{N}=120)$

\begin{tabular}{|c|c|c|}
\hline \multicolumn{3}{|c|}{ Age } \\
\hline Category & Frequency & Percentage \\
\hline Young (25- 35 years) & 12 & 10.00 \\
\hline Middle (35 - 55 years) & 78 & 65.00 \\
\hline Old (Above 55 years) & 30 & 25.00 \\
\hline \multicolumn{3}{|c|}{ Education } \\
\hline Category & Frequency & Percentage \\
\hline Low (illiterate+primary) & 14 & 11.67 \\
\hline Medium (6-12) & 66 & 55.00 \\
\hline High(above 12) & 40 & 33.33 \\
\hline \multicolumn{3}{|l|}{ Size of Land Holding } \\
\hline Low (Less than 1 hectare) & 22 & 18.34 \\
\hline Medium (1-2 hectares) & 44 & 36.66 \\
\hline High (more than 2 hectares) & 54 & 45.00 \\
\hline \multicolumn{3}{|l|}{ Annual Income } \\
\hline Low (up to Rs.40,000) & 16 & 13.34 \\
\hline Medium (Rs. 40,001-80,000) & 37 & 30.83 \\
\hline High (above 80,000 ) & 67 & 55.83 \\
\hline \multicolumn{3}{|l|}{ Mass Media Exposure } \\
\hline Low & 38 & 31.67 \\
\hline Medium & 50 & 41.67 \\
\hline High & 32 & 26.66 \\
\hline \multicolumn{3}{|l|}{ Extension Contacts } \\
\hline Low & 41 & 34.17 \\
\hline Medium & 50 & 41.67 \\
\hline High & 29 & 24.16 \\
\hline \multicolumn{3}{|l|}{ Economic Motivation } \\
\hline Low & 32 & 26.67 \\
\hline Medium & 54 & 45.00 \\
\hline High & 34 & 28.33 \\
\hline
\end{tabular}




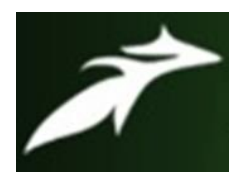

Saurabh Mishra et al, International Journal of Advances in Agricultural Science and Technology, Vol.8 Issue.7, July-2021, pg. 69-75

ISSN: 2348-1358

Impact Factor: 6.057

NAAS Rating: 3.77

Table-1.Shows that majority (65.00\%) of respondents belongs to middle level of age group. It was observed that $(55.00 \%)$ of the respondents belongs to medium level (literate upto intermediate) category. It was found that $(45.00 \%)$ of the respondents belongs to high level land holding (>2 ha), similarly it was observed that (55.83\%) of the respondents belongs to high level of income i.e. above 80,000). It was found that $(41.67 \%)$ of the respondents belongs to medium level of mass media exposure category,(41.67\%) of the respondents belongs to medium level extension contacts category, $(45.00 \%)$ of the respondents belongs to medium level economic motivation category. Similar result is also reported by Kumar and Bose (2013)

TABLE-2 KNOWLEDGE OF RESPONDENTS REGARDING WHEAT PACKAGE OF PRACTICES

\begin{tabular}{|c|c|c|c|c|}
\hline \multirow[b]{2}{*}{ Sl.No. } & \multirow[b]{2}{*}{ Statements } & \multicolumn{3}{|c|}{ Evaluation } \\
\hline & & $\begin{array}{c}\text { Fully correct } \\
\text { F(\%) }\end{array}$ & $\begin{array}{c}\text { Partially correct } \\
\text { F }(\%)\end{array}$ & $\begin{array}{c}\text { Not correct } \\
F(\%)\end{array}$ \\
\hline 1. & $\begin{array}{l}\text { Field preparation: } \\
\begin{aligned} \text { i. } & \text { Traditional method- } 2-3 \text { times } \\
& \text { ploughing } \\
\text { ii. } & \text { Use of zero tillage machine } \\
\text { iii. } & \text { Surface seeding method }\end{aligned}\end{array}$ & $60(50.00 \%)$ & $42(35.00 \%)$ & $18(15.00 \%)$ \\
\hline 2. & \begin{tabular}{|cl}
\multicolumn{2}{|l}{ Improved variety: } \\
$\begin{array}{cl}\text { i. } & \text { Kudrat-5 } \\
\text { ii. } & \text { Kudrat-9 } \\
\text { iii. } & \text { Kudrat-17 }\end{array}$
\end{tabular} & $42(35.00 \%)$ & $47(39.17 \%)$ & $31(25.83 \%)$ \\
\hline 3. & \begin{aligned} & \multicolumn{2}{l}{ Seed and its treatment: } \\
& i. Vitavax \\
& ii. Carbendazim \\
& iii. Pseudomonas fluorescens \end{aligned} & $20(16.16 \%)$ & $64(53.34 \%)$ & $36(30 \%)$ \\
\hline 4. & $\begin{array}{l}\text { Sowing time: } \\
\text { i. } 25 \text { october-November } \\
\text { ii. } \quad \text { Nov to December }\end{array}$ & $41(34.17 \%))$ & $51(42.50 \%)$ & $28(23.33 \%)$ \\
\hline 5. & $\begin{array}{ll}\text { Spacing: } \\
\begin{array}{cl}\text { i. } & 22.5 \text { to } 23 \mathrm{~cm} \\
\text { ii. } & 15 \text { to } 18 \mathrm{~cm} \\
\text { iii. } & 20-22.5 \mathrm{~cm}\end{array}\end{array}$ & $40(33.33 \%)$ & $51(42.50 \%)$ & $29(24.17 \%)$ \\
\hline 6. & $\begin{aligned} \text { Fertilizers: } \\
\begin{aligned} \text { i. } & 120: 60: 40 \mathrm{Kg} \mathrm{NPK} / \mathrm{ha} \\
\text { ii. } & 90: 60: 40 \mathrm{~kg} \mathrm{NPK} / \mathrm{ha}\end{aligned}\end{aligned}$ & $24(20.00 \%)$ & $74(61.66 \%)$ & $22(18.34 \%)$ \\
\hline
\end{tabular}




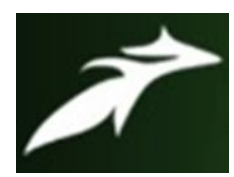

Saurabh Mishra et al, International Journal of Advances in Agricultural Science and Technology, Vol.8 Issue.7, July-2021, pg. 69-75

ISSN: 2348-1358

Impact Factor: 6.057

NAAS Rating: 3.77

\begin{tabular}{|c|c|c|c|c|}
\hline \multirow[b]{2}{*}{7.} & Irrigation: & \multirow[b]{2}{*}{$33(27.50 \%)$} & \multirow[b]{2}{*}{$60(50.00 \%)$} & \multirow[b]{2}{*}{$27(22.50 \%)$} \\
\hline & \begin{tabular}{|rl} 
i. & 2times \\
ii. & 3times \\
iii. & 6times
\end{tabular} & & & \\
\hline 8. & $\begin{array}{l}\text { Weeding and hoeing operations: } \\
\begin{array}{cl}\text { i. } & \text { 2times } \\
\text { ii. } & \text { 3times } \\
\text { iii. } & 4 \text { times }\end{array}\end{array}$ & $11(9.17 \%)$ & $47(39.16 \%)$ & $62(51.67 \%)$ \\
\hline 9. & \begin{aligned} & \multicolumn{2}{l}{ Weed control: } \\
& i. Sulfosulfuron \\
& ii. Metribuzin \\
& iii. Clodinafop \\
& iv. Fenoxaprop-p-ethyl \end{aligned} & $21(17.5 \%)$ & $71(59.16 \%)$ & $28(23.34 \%)$ \\
\hline 10. & \begin{tabular}{cl}
\multicolumn{2}{l}{ Diseases: } \\
i. & Yellow rust \\
ii. & Black rust \\
iii. & Common bunt \\
iv. & Common root rot \\
v. & Leaf blight
\end{tabular} & $32(26.67 \%)$ & $45(37.5 \%)$ & $43(35.83 \%)$ \\
\hline 11. & \begin{tabular}{ll}
\multicolumn{2}{l}{ Harvesting: } \\
$\begin{array}{cl}\text { i. } & \text { 80-90days } \\
\text { ii. } & 90-100 \text { days } \\
\text { iii. } & 100-110 \text { days } \\
\text { iv. } & 110-120 \text { days }\end{array}$
\end{tabular} & $33(27.50 \%)$ & $37(30.83 \%)$ & $50(41.67 \%)$ \\
\hline 12. & \begin{tabular}{|cc} 
Yield: & \\
i. & $35-40$ quintal/ha \\
ii. & $20-25$ quintal/ha \\
iii. & 15-20quintal/ha \\
iv. & $25-35$ quintal/ha
\end{tabular} & $23(19.17 \%)$ & $77(64.17 \%)$ & $20(16.66 \%)$ \\
\hline
\end{tabular}




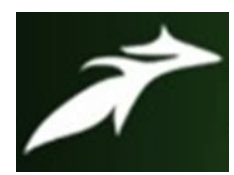

Saurabh Mishra et al, International Journal of Advances in Agricultural Science and Technology,

Vol.8 Issue.7, July-2021, pg. 69-75

ISSN: 2348-1358

Impact Factor: 6.057

NAAS Rating: 3.77

Table 3:- Overall Knowledge level of farmers towards improved wheat production practices of the respondents. $(\mathbf{N}=\mathbf{1 2 0})$

\begin{tabular}{|c|c|c|c|}
\hline \multicolumn{4}{|c|}{ Knowledge Level } \\
\hline Category & $\begin{array}{c}\text { Knowledge } \\
\text { Score }\end{array}$ & Frequency & Percentage \\
\hline Low level & $13-20$ & 25 & 20.83 \\
\hline Medium level & $21-27$ & 65 & 54.17 \\
\hline High level & $28-34$ & 30 & 25.00 \\
\hline \multicolumn{2}{|c|}{ Total } & $\mathbf{1 2 0}$ & $\mathbf{1 0 0 . 0 0}$ \\
\hline
\end{tabular}

Table-3 reveals that majority of the respondents (54.17\%) fell in the medium knowledge level group, whereas $(25.00 \%)$ per cent respondents were observed in the high knowledge level group and remaining (20.83\%) per cent respondents formed low knowledge level group. It is concluded that majority of farmers were having medium knowledge level followed by high and low knowledge level respectively. The similar results were also observed by Ram (2017) Reddy (2007) and Singh (2003).

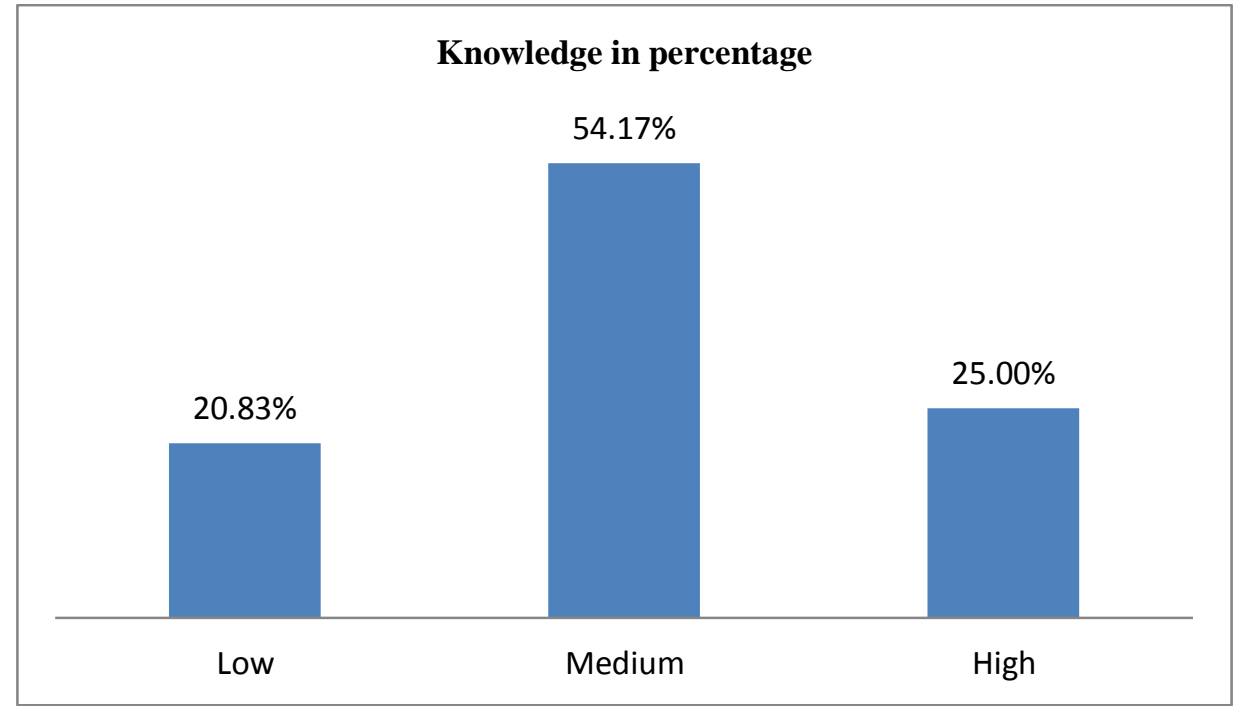

Fig. 1 -Table 3 Knowledge in percentage of respondents 


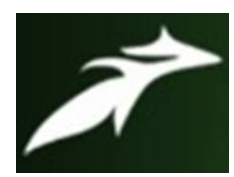

Saurabh Mishra et al, International Journal of Advances in Agricultural Science and Technology, Vol.8 Issue.7, July-2021, pg. 69-75

ISSN: 2348-1358

Impact Factor: 6.057

NAAS Rating: 3.77

Table 4:- Relationship between the selected independent variables with knowledge of farmers towards improved wheat production practices. $(\mathrm{N}=120)$.

\begin{tabular}{|c|c|c|}
\hline $\begin{array}{l}\text { Sr. } \\
\text { No. }\end{array}$ & Variables & Correlation coefficient ('r' value) \\
\hline 1. & Age & $0.9884713^{*}$ \\
\hline 2. & Education & $0.91766294 *$ \\
\hline 3. & Size of Land holding & $0.32231732 *$ \\
\hline 4. & Annual income & $0.0134255 \mathrm{NS}$ \\
\hline 5. & Mass media exposure & $0.9011271^{*}$ \\
\hline 6. & Extension contacts & $0.75124363^{*}$ \\
\hline 7. & \multirow{2}{*}{\multicolumn{2}{|c|}{\begin{tabular}{l|r} 
Economic motivation & $0.9994664^{*}$ \\
\multicolumn{2}{|c|}{ Significant at 0.05 level of probability. }
\end{tabular}}} \\
\hline$*$ & & \\
\hline$* *$ & \multicolumn{2}{|c|}{ Significant at 0.01 level of probability. } \\
\hline NS & \multicolumn{2}{|c|}{ Non Significant. } \\
\hline
\end{tabular}

Table-4 indicated that out of seven independent variables, six variables are i.e. age, education, size of land holding, mass media exposure, extension contacts, economic motivation positively and significantly correlated with knowledge of farmers towards improved wheat production practices whereas the independent variable annual income of the respondents was availed negatively and non- significantly correlated with knowledge of farmers towards improved wheat production practices.

\section{CONCLUSION}

It was concluded that the socio-economic profile of the sample group were medium level. It was evident that the knowledge of farmers towards improved wheat production practices were found medium level. The factors influencing in knowledge of farmers towards improved wheat production practices are age, education, size of land holdings, mass media exposure, extension contacts, and economic motivation. Farmers should be trained by the Agriculture Scientists for seed treatment and timely availability of chemical specially culture should be ensured either by the Agriculture University or State Department of Agriculture. A regular mass media support at the appropriate time in the form of ratio talks, television programmes and technical articles in the newspaper, magazines etc. should be ensured for equipping the farmers with latest wheat production technologies. 


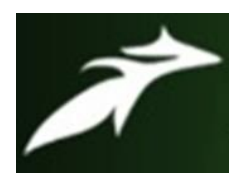

Saurabh Mishra et al, International Journal of Advances in Agricultural Science and Technology,

Vol.8 Issue.7, July-2021, pg. 69-75

ISSN: 2348-1358

Impact Factor: 6.057

NAAS Rating: 3.77

\section{REFERENCES}

[1]. Singh Anvesha, Kumar Sunil Sri, Tiwari Krishna Gopal, Devi Laxmi and Babulal. 2020. A Statistical Study of Trends of Wheat Production in Districts of Eastern Uttar Pradesh. Int.J.Curr.Microbiol.App.Sci. 9(04): 158-166.

[2]. Bose, D.K., Maurya, O.P. and Rai, A.K. (2019)Adoption behaviour of farmers about recommended wheat production practices in Prayagraj district of Uttar Pradesh. International Journal of Innovation Science and Research Technology, vol-4, issue-9; 2456-2165.

[3]. Kumar, J., Bose, Dipak Kumar (2013) Adoption Behaviour of Pigeonpea Growers in Allahabad District of Uttar Pradesh. Jour. of Ext. Edu., IARI, New Delhi, Vol-49, pp: 110-111.

[4]. Ram, et al. (2017), "Response of wheat (Triticum aesortivum) genotypes to different tillage practices for improving productivity and seed quality in eastern Indo- Gangetic plains of India", Indian Journal of Agricultural Sciences, Vol. 87, No. 10 p.1324-8.

[5]. Reddy, Shashidhar, D.N., (2007). A study on influencing factors and constraints in drip irrigation by horticulture farmers of Bijapur district of Karnataka. M.Sc. (Agril.) Thesis, University of Agricultural Sciences, Dharwad.

[6]. Singh, Puspendra, Naruka and Singh Sangram (2003). A study on knowledge level of soybean growers about improved soybean production technology, Maharashtra Journal of Extension Education 22: 1-4. 